The Problems of a

Political Animal 



\section{The Problems of a Political Animal}

Community, Justice, and Conflict in Aristotelian Political Thought

Bernard Yack 
University of California Press

Berkeley and Los Angeles, California

University of California Press, Ltd.

London, England

(C) 1993 by

The Regents of the University of California

Library of Congress Cataloging-in-Publication Data

Yack, Bernard, 1952-

The problems of a political animal : community, justice, and conflict in Aristotelian political thought / Bernard Yack.

p. $\mathrm{cm}$.

Includes bibliographical references and index.

ISBN 0-520-08166-8 (alk. paper). - ISBN 0-520-08167-6 (pbk. : alk. paper)

1. Aristotle-Contributions in political science. 2. Community. 3. Justice.

4. Social conflict. I. Title.

JC71.A7Y34 1993

$320^{\prime} .01^{\prime} 1$ - dc20

92-23296

CIP

Printed in the United States of America

987654321

The paper used in this publication meets the minimum requirements of American $\mathrm{Na}$ tional Standard for Information Sciences-Permanence of Paper for Printed Library Materials, ANSI Z39.48-1984. () 
In memory of Judith Nisse Shklar (1929-1992) 
